\title{
Choice of sterilizing/disinfecting agent - determination of the Decimal ReductionTime (D-Value)
}

\author{
Priscila Gava Mazzola ${ }^{1, *}$, Angela Faustino Jozala ${ }^{2}$, Letícia Célia de Lencastre Novaes ${ }^{2}$, Patricia \\ Moriel $^{1}$, Thereza Christina Vessoni Penna ${ }^{2}$
}

\author{
${ }^{1}$ Department of Clinical Pathology, Faculty of Medical Sciences, Campinas State University, ${ }^{2}$ Department of Biochemical and \\ Pharmaceutical Technology, Faculty of Pharmaceutical Sciences, University of São Paulo
}

\begin{abstract}
Efforts to diminish the transmission of infections include programs in which disinfectants play a crucial role. Hospital surfaces and medical devices are potential sources of cross contamination, and each instrument, surface or area in a health care unit can be responsible for spread of infection. The decimal reduction time was used to study and compare the behavior of selected strains of microorganisms. The highest $\mathrm{D}$-values for various bacteria were obtained for the following solutions: (i) $0.1 \%$ sodium dichloroisocyanurate ( $\mathrm{pH} 7.0)-E$. coli and A. calcoaceticus ( $\mathrm{D}=5.9 \mathrm{~min}$ ); (ii) sodium hypochlorite $(\mathrm{pH} 7.0)$ at $0.025 \%$ for B. stearothermophilus $(\mathrm{D}=24 \mathrm{~min})$, E. coli and E. cloacae $(\mathrm{D}=7.5 \mathrm{~min})$; at $0.05 \%$ for $B$. stearothermophilus $(\mathrm{D}=9.4 \mathrm{~min})$ and $\mathrm{E}$. coli $(\mathrm{D}=6.1 \mathrm{~min})$. The suspension studies were an indication of the disinfectant efficacy on a surface. The data in this study reflect the formulations used and may vary from product to product. The expected effectiveness from the studied formulations shows that the tested agents can be recommended for surface disinfection as stated in present guidelines and emphasize the importance and need to develop routine and novel programs to evaluate product utility.
\end{abstract}

Uniterms: Disinfection. Disinfectant agents. Decimal reduction time/determination.

Esforços para diminuir o risco de transmissões de infecções incluem programas nos quais os desinfetantes desempenham papel crucial. As superfícies de materiais médico-hospitalares, se não estiverem diretamente ligados à transmissão de doenças, podem contribuir, potencialmente, para uma contaminação cruzada secundária. Cada instrumento ou superfície do estabelecimento do ambiente de saúde que entra em contato com um paciente é um disseminador potencial de infecção. Para estudar e comparar o comportamento dos microrganismos selecionados foram realizados ensaios de determinação do tempo de redução decimal. Os maiores valores $\mathrm{D}$ determinados, foram: (i) $0,1 \%$ dicloroisocianurato de sódio $(\mathrm{NaDCC})(\mathrm{pH} 7.0)-E$. coli e A. calcoaceticus $(\mathrm{D}=5,9 \mathrm{~min})$; (ii) hipoclorito de sódio $(\mathrm{pH} 7,0)$ à $0,025 \%$ para $B$. stearothermophilus $(\mathrm{D}=24 \mathrm{~min})$, E. coli e E. cloacae $(\mathrm{D}=7,5 \mathrm{~min})$; e à $0,05 \%$ para $B$. stearothermophilus $(\mathrm{D}=9,4 \mathrm{~min}) \mathrm{e}$ E. coli $(\mathrm{D}=6,1 \mathrm{~min})$. Este estudo estabelece que as suspensões estudadas são indicação da eficácia de desinfecção recomendada pela legislação, mas os resultados podem variar de produto para produto. Para desinfecção de mãos clorexidina pode ser utilizada, pois apresentou valores D baixos. Para desinfecção de nível intermediário de equipamentos e instrumentos recomenda-se a utilização de NaDCC, devido à estabilidade e baixo efeito corrosivo para equipamentos e materiais. Glutaraldeído, apesar de muito aceito para processos esterilizantes, tem eficácia comparável a soluções de formaldeído.

Unitermos: Deseinfecção. Agentes desinfetantes. Tempo de redução decimal/determinação.

\section{INTRODUCTION}

Hospitals and health care units must have cleaning

\footnotetext{
"Correspondence: P. G. Mazzola. Departamento de Tecnologia BioquímicoFarmacêutica, Faculdade de Ciências Farmacêuticas, Universidade de São Paulo, Av. Professor Lineu Prestes, 580, Bloco 16 - Cidade Universitária, 05508-900 - São Paulo - SP, Brasil. E-mail: pmazzola@usp.br
}

and disinfection programs to guarantee that materials and environment are safe from infectious agents. These cleaning programs should remove organic and inorganic contaminants, facilitating the contact between the sanitizing agent and the microorganism (Rutala, 1998).

Any decontamination program should begin with a cleaning method to reduce the initial number of viable 
microorganisms (bioburden) present on the material or equipment to be disinfected, to guarantee the success of subsequent disinfection or sterilization (Jacobs et al., 1998).

An effective disinfection program depends upon the correct selection of chemical agents as well as an adequate application method. The specific needs of a particular item, surface or ambient should be well understood, as should the properties of the chemicals to be used.

Using predetermined conditions (Mandigan et al., 2002; Brasil, 1988, 1999, 2001), antimicrobial agents can be classified according to the level of disinfection provided, into four groups:

(i) antiseptics - chemical agents which inhibit microbial growth, are non toxic for live tissues, and are used to decontaminate hands or superficial wounds;

(ii) disinfectants - physical or chemical agents which irreversibly inactivate or destroy the majority of pathogenic organisms, but not necessarily spores or all viruses;

(iii) sanitizing agents - chemical agents used to reduce microorganisms to a level acceptable according to public health regulations. The principal difference between a sanitizing agent and a disinfectant is that the latter has a greater capacity to decrease the population of pathogenic microorganisms:

(iv) sterilizing agents - these are high level disinfectants which in certain circumstances can guarantee sterilization as they remove all viable forms of microorganisms from objects and surfaces. This includes removal or permanent inactivation of viruses and bacterial spores. Sterilization results in a total absence of viable microorganisms, and as it refers to an absolute condition, provides a greater margin of safety compared to any other antimicrobial method (ISO 14937, ISO 11134).

Classification of the level of disinfection or sterilization of a chemical agent depends on the resistance of the microorganism to these processes. Evaluation of microbacterial resistance to a sterilizing agent is done in two stages: the first is qualitative, and consists of the minimum concentration needed to reduce the initial microbial concentration to pre- established levels; while the second stage evaluates the contact time needed between the microbe and the sanitizing agent. This microbial resistance parameter is evaluated by the decimal reduction time ( $\mathrm{D}$ value).

Depending upon the efficiency of the chemical agent tested, the disinfection process can be classified (Spaulding, 1968) as: high level (sterilization activity present); intermediate level (inactivation of Mycobacterium tuberculosis and the most resistant types of viruses); and low level (reduction of the initial level of contami- nants). Low levels and intermediate levels of disinfection are not capable of destroying sporulated microorganisms (Penna et al., 2001).

In order to fulfill pre-established standards, it is crucial to choose a chemical agent that which will effectively decontaminate the item or area under consideration, as well as to know which microorganism is likely to be present (Croshaw, 1981).

The effectiveness of a disinfectant or process of disinfection can be affected by (i) previous cleaning of the material, (ii) disinfectant concentration, (iii) duration of application, (iv) final $\mathrm{pH}$ value, and (v) temperature during the disinfection process.

Brazilian legislation (Brasil 1988,1998) lists the chemical agents and recommendations for correct application, safety limits in relation to tolerated toxicity, and prohibited agents. The legislation also created a Control of Hospital Infections Committee (CHIC) and Control of Hospital Infections Program (CHIP), as well as defining procedures to minimize nosocomial infections caused by an elevated microbial level (bioburden) typical in this type of environment. In Brazil, fewer than $20 \%$ of hospitals have an adequate hospital infection control program (Agência Estado on line, accessed in January, 2001).

The following microorganisms were selected for the present study: Staphylococcus aureus, Escherichia coli, Enterobacter cloacae, Serratia marcescens e Acinetobacter calcoaceticus based on outbreaks of hospital infections reported by the media in the years spanning from 1996-2001 (Penna et al., 2001; Agência Estado on line, accessed in January, 2001). These were evaluated as to their resistance to the most commonly used hospital sanitizing agents. Bacillus subtilis and Bacillus stearothermophilus were also tested as they are spore formers and known biologic indicators used for various disinfection and sterilization processes.

The resistance study used was the decimal reduction time method (D value). Confidence levels selected were a reduction of 6 and $12 \log _{10}$ of bioburden, guaranteeing that the probability of microorganism survival would be $10^{-1}$ or lower.

The $\mathrm{D}$ value or the decimal reduction time value is the time taken, at a constant temperature, for the treatment to result in a $90 \%$ reduction (1 logarithmic cycle) of the microbial population initially present in the product. Mathematically, the $\mathrm{D}$ value is calculated from the negative inverse angular coefficient of rotation of the straight line equation, using the method of linear regression and least squares, applied to the linear part of the survival curve (Penna et al., 2001; Mazzola et al., 2003). 


\section{MATERIAL AND METHODS}

\section{Material}

The tested microorganisms were purchased from ATCC (American Type Culture Collection) or from the Adolfo Lutz Institute (ALI). Culture media, peracetic acid, iodine, hydrogen peroxide and other reagents were purchased from Sigma (St. Louis, MO). The chemical agents chlorhexidine gluconate, quaternary ammonium compound, gluteraldehyde, and formaldehyde were kindly provided by Aster Produtos Médicos Ltda. (Sorocaba, SP), while sodium dicloroisocyanurate $(\mathrm{NaDCC})$ was kindly provided by Johnson \& Johnson, while Edwards Lifesciences Macchi graciously gave commercial solutions of Minncare ${ }^{\circledR}$ (a solution of hydrogen peroxide $2.2 \%$ and peracetic acid $0.45 \%$ ). Compounds liberating active chlorine were prepared from a commercial solution of concentrated sodium hypochlorite. The chloride, hydrogen peroxide and iodine concentrations were determined using the iodometric method (Baccan et al., 1985).

\section{Inoculum preparation}

The cultures were maintained in a suspension of soya casein (TSA, Difco, Detroit, Michigan, USA) at $4{ }^{\circ} \mathrm{C}$ with weekly transfers. After 24 hours they were developed in TSA at $22{ }^{\circ} \mathrm{C}$ for $S$. marcencens, and at $35-37^{\circ} \mathrm{C}$ for E. cloacae, A. calcoaceticus, E. coli, $S$. aureus. They were then transferred to SBT (Difco), centrifuged $\left(1000 \mathrm{~g} / 15 \mathrm{~min} / 4^{\circ} \mathrm{C}\right.$ ) and resuspended in saline solution. The bacterial viability was estimated from a deep SAT culture confirming populations with concentrations greater than $10^{7} \mathrm{CFU} / \mathrm{mL}$.

Spore cultures were grown for 6 days in sporulation medium (containing $\mathrm{D}(+)$ glucose, L-glutamic acid, yeast extract, peptone, sodium chlorate, manganese sulphate, bacterial agar, distilled water), at $37^{\circ} \mathrm{C}$ for $B$. subtilis, and at $62{ }^{\circ} \mathrm{C}$ for B.stearothermophilus. These were than transferred, centrifuged ( $1935 \mathrm{~g}$ for $30 \mathrm{~min}$, four times) and the suspension maintained at $4{ }^{\circ} \mathrm{C}$ in a calcium acetate solution $(\mathrm{pH}=9.7)$ (Penna et al., 1998). After a thermal shock to activate them $\left(80^{\circ} \mathrm{C} / 10 \mathrm{~min}\right.$ for $B$. subtilis and $100^{\circ} \mathrm{C} / 20 \mathrm{~min}$ for $B$. stearothermophilus), the viability of the spores was measured by deep culture in SAT, which confirmed populations of greater than $10^{6}$ spores $/ \mathrm{mL}$.

\section{Decimal reduction time ( $\mathrm{D}$ value)}

Decimal reduction time D value was obtained by transferring $1 \mathrm{~mL}$ suspension of a known concentration of microorganisms into $99 \mathrm{~mL}$ of a test disinfecting solution maintained with constant magnet agitation at room temperature $\left(25^{\circ} \mathrm{C}\right)$. Initial concentration of microorganisms $\left(\mathrm{N}_{\mathrm{o}}\right)$ in contact with the disinfecting agent varied between $10^{5}-10^{6} \mathrm{CFU} / \mathrm{mL}$ : the $\mathrm{d}$ values were plotted as a graph of $\log C F U / m L x$ time (min) (see example curve in Figure 1).

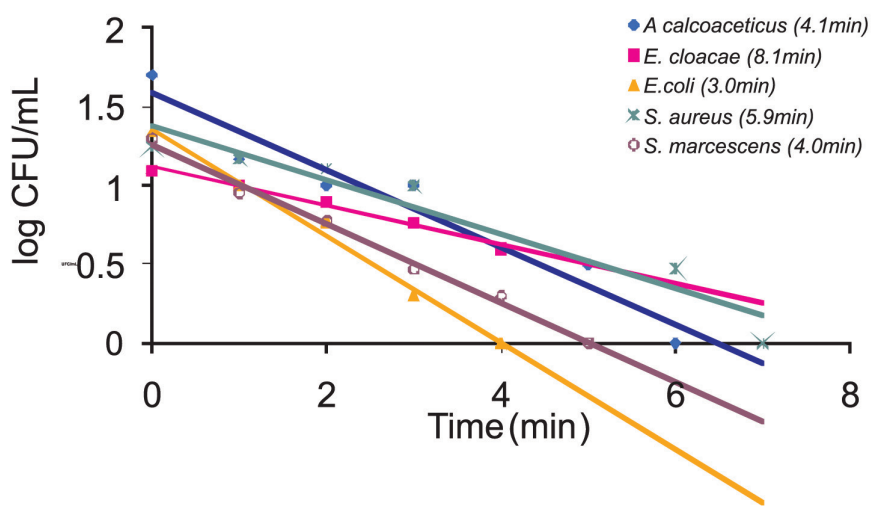

FIGURE 1 - Example of an exponential decay curve in the number of organisms in contact with the disinfecting solution. The above curve refers to a solution of chlorhexidine $4000 \mathrm{mg} / \mathrm{mL}$ and vegetative cells of A. calcoaceticus, E. cloacae, A. calcoaceticus, E. coli and S. aureus.

At regular time intervals ( 1 minute for vegetative cells and 5 minutes for spore forming cells), $1 \mathrm{~mL}$ of the sample mixture ( sanitizing agent and microbial suspension) was transferred to $9 \mathrm{~mL}$ of sterile SBT culture (Figure 2). Subsequently, the number of viable microorganisms was determined by deep plating on sterile Petri dishes with nonselective culture medium (plate count agar, PCA). Prior to plating, each tube containing $9 \mathrm{~mL}$ of culture medium and $1 \mathrm{~mL}$ of sanitizing and agent and microorganism mixture was diluted in physiologic solution $(0.9 \mathrm{NaCl})$ in successive dilutions to determine microorganism concentration $\left(10^{-1}\right.$, $10^{-2}, 10^{-3}, 10^{-4}$, etc)

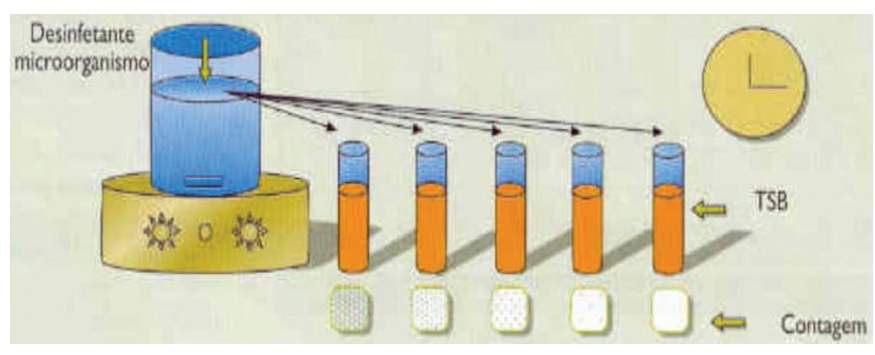

FIGURE 2 - Representation of decimal reduction time method (D value).

\section{Microorganisms and disinfectant/SBT/Count}

After plating, the plaques were incubated in a sterilizer at the optimum growth temperature for each organism. 
After 24 hours, the number of colony forming units (CFU)/ $\mathrm{mL}$ were counted and the curves of $\log \mathrm{CFU} / \mathrm{mL}$ versus time (in minutes) were built (see Figure 1 for example of exponential decay curve). The total exposed time was calculated as 6 times the D value (ISO 14937, USP 24).

\section{RESULTS AND DISCUSSION}

Classification of the activity spectrum of each sanitizing agent according to the D value for each microorganism tested facilitates the development of a cleaning, disinfection and sterilization program for hospital environments (Croshaw, 1981, ISO 11134). It is important to state that there is no disinfecting agent suitable for use in all situations, due to pre-established specifications for use (Croshaw, 1981, ISO 11134).

The process of disinfection was monitored using two biological indicators: the $\mathrm{D}$ value and the initial population $\left(\mathrm{N}_{\mathrm{o}}\right)$ (Penna et al., 2001). The initial treatment was designed to inactivate the initial bioburden $\left(>10^{4} \mathrm{CFU} / \mathrm{mL}\right)$ and guarantee additional security by a considerably reducing the concentration of microorganisms. The $\mathrm{D}$ values and the security factors are found in Table I.

In general, a disinfectant should be able to reduce pathogenic bacteria by $3 \log _{10}$ in 30 seconds and by 5-6 $\log _{10}$ in a period of between 5 to 10 minutes (Rutala, 1995). However, elimination of spores requires a prolonged contact time and specific chemical agents to obtain the necessary confidence interval (reduction by $12 \log _{10}$ ).

Vegetative cells of E. cloacae e $S$. aureus, showed a higher resistance to $0.4 \%$ chlorhexidine: the $\mathrm{D}$ values of these microorganisms were about 1.5 times greater than those found for A. calcoaceticus, S. marcescens and $E$. coli. Whereas only 3 to 4 minutes was needed for a $90 \%$ reduction of populations of de $E$. coli, S. marcescens and $A$. calcoaceticus, a reduction of $3 \log _{10}$ for vegetative strains required 9 to 12 minutes (Table I).

Spore forming strains exposed to a $2 \%$ solution of chlorhexidine and $B$. stearothermophilus showed approximately 1.4 times greater resistance than $B$. subtilis. In general however, solutions of chlorhexidine do not have much activity against spore forming microorganisms, and it is probable that the activity observed was due to inactivation of vegetative cells in the spore suspension, which was a mixture of both spores and vegetative cells (Table I).

The immersion times necessary for medical and dental instruments are: (i) a low level disinfection of 50 - 100 minutes in $0.4 \%$ chlorhexidine solution for a $6-12$ $\log _{10}$ reduction in the number of vegetative cells, followed by (ii) immersion in $2 \%$ chlorhexidine solution for $80-100$ minutes to attain a high level of disinfection (Table I).

B. stearothermophilus and B. subtilis showed similar $D$ values when exposed to a $0.5 \%$ formaldehyde solution which indicated a resistance double that found for $A$. calcoaceticus and E. cloacae, and 5 times higher that the resistance level determined for $S$. marcescens, which was the most sensitive.

Formaldehyde solutions of $4 \%$ are considered disinfectants of the highest level in Brazilian hospitals, and are used for 24 hour disinfection of the capillaries in dialysis systems. For disinfection of semi-critical items, an $8 \%$ formaldehyde in an alcohol based solution or a $10 \%$ formaldehyde aqueous based solution is used, for 18 hours. Brazilian hospitals employ a $4 \%$ solution of formaldehyde for 30 minutes to four hours for low level disinfection of equipment and medical items (Brasil, 1988, 1999).

TABLE I - Decimal reduction time (D Values) for bacteria studied for different chemical agent solutions. Includes concentration of chemical agents, survival data and $\mathrm{D}$ value.

\begin{tabular}{|c|c|c|c|c|c|c|c|}
\hline Disinfecting Solution & Bacteria & $\begin{array}{c}\text { Disinfectant } \\
(\%)\end{array}$ & $\begin{array}{l}\text { Concentration } \\
\quad(\mathrm{mg} / \mathrm{L})\end{array}$ & $\begin{array}{c}\text { Survivors }^{1} \\
\log n\end{array}$ & $\begin{array}{l}\text { D Value } \\
\text { (min) }\end{array}$ & $\begin{array}{c}{ }^{2} \mathrm{t}=\mathrm{n} \times \mathrm{D} \\
{ }^{3,4} \mathrm{n}=6-\log _{10} \\
\quad(\min )\end{array}$ & $\begin{array}{c}{ }^{2} \mathrm{t}=\mathrm{n} \times \mathrm{D} \\
{ }^{3,4} \mathrm{n}=12-\log _{10} \\
(\mathrm{~min})\end{array}$ \\
\hline \multirow[t]{7}{*}{$\operatorname{NaDCC}(\mathrm{pH}=7,0)$} & A. calcoaceticus & 0,1 & 1000 & $-0,17 \mathrm{t}$ & 5,9 & 35,4 & 70,8 \\
\hline & E. cloacae & 0,1 & 1000 & $-0,21 \mathrm{t}$ & 4,7 & 28,2 & 56,4 \\
\hline & E. coli & 0,1 & 1000 & $-0,17 \mathrm{t}$ & 5,9 & 35,4 & 70,8 \\
\hline & S. aureus & 0,1 & 1000 & $-0,20 \mathrm{t}$ & 5 & 30 & 60 \\
\hline & S. marcescens & 0,1 & 1000 & $-0,23 \mathrm{t}$ & 4,3 & 25,8 & 51,6 \\
\hline & B. stearothermophilus & 0,2 & 2000 & $-0,22 \mathrm{t}$ & 4,4 & 26,6 & 53,3 \\
\hline & B. subtilis & 0,2 & 2000 & $-0,26 \mathrm{t}$ & 3,8 & 22,5 & 45 \\
\hline \multirow{5}{*}{$\begin{array}{l}\text { SODIUM } \\
\text { HYPOCHLORITE } \\
(\mathrm{pH}=7.0)\end{array}$} & E. coli & 0,05 & 500 & $-0,16 \mathrm{t}$ & 6,1 & 36,4 & 72,9 \\
\hline & B. stearothermophilus & 0,05 & 500 & $-0,106 t$ & 9,4 & 56,4 & 112,8 \\
\hline & B. subtilis & 0,05 & 500 & $-0,097 \mathrm{t}$ & 10,3 & 61,8 & 123,6 \\
\hline & B. stearothermophilus & 0,1 & 1000 & $-0,28 \mathrm{t}$ & 3,5 & 20,9 & 41,8 \\
\hline & B. subtilis & 0,1 & 1000 & $-0,31 \mathrm{t}$ & 3,2 & 19,2 & 38,3 \\
\hline
\end{tabular}


TABLE I - Decimal reduction time (D Values) for bacteria studied for different chemical agent solutions. Includes concentration of chemical agents, survival data and D value. (cont.)

\begin{tabular}{|c|c|c|c|c|c|c|c|}
\hline Disinfecting Solution & Bacteria & $\begin{array}{c}\text { Disinfectant } \\
(\%)\end{array}$ & $\begin{array}{l}\text { Concentration } \\
(\mathrm{mg} / \mathrm{L})\end{array}$ & $\begin{array}{c}\text { Survivors }^{1} \\
\log \mathrm{n}\end{array}$ & $\begin{array}{c}\text { D Value } \\
\text { (min) }\end{array}$ & $\begin{array}{c}{ }^{2} \mathrm{t}=\mathrm{n} \times \mathrm{D} \\
{ }^{3,4} \mathrm{n}=6-\log _{10} \\
\quad(\min )\end{array}$ & $\begin{array}{c}{ }^{2} \mathrm{t}=\mathrm{n} \times \mathrm{D} \\
{ }^{3,4} \mathrm{n}=12-\log _{10} \\
(\mathrm{~min})\end{array}$ \\
\hline \multirow{7}{*}{$\begin{array}{l}\text { SODIUM } \\
\text { HYPOCHLORITE } \\
(\mathrm{pH}=7.0)\end{array}$} & A. calcoaceticus & 0,025 & 250 & $-0,16 \mathrm{t}$ & 6,2 & 37,3 & 74,6 \\
\hline & E. cloacae & 0,025 & 250 & $-0,13 \mathrm{t}$ & 7,5 & 44,8 & 89,6 \\
\hline & E. coli & 0,025 & 250 & $-0,13 \mathrm{t}$ & 7,5 & 45,1 & 90,1 \\
\hline & S. aureus & 0,025 & 250 & $-0,21 \mathrm{t}$ & 4,7 & 27,9 & 55,8 \\
\hline & S. marcescens & 0,025 & 250 & $-0,149 \mathrm{t}$ & 6,7 & 40,1 & 80,2 \\
\hline & B. stearothermophilus & 0,025 & 250 & $-0,041 \mathrm{t}$ & 24 & 144 & 288 \\
\hline & B. subtilis & 0,025 & 250 & $-0,048 \mathrm{t}$ & 20,6 & 123,6 & 247,2 \\
\hline \multicolumn{2}{|c|}{ GLUTARALDEHYDE A. calcoaceticus } & 2 & 20000 & $-0,21 \mathrm{t}$ & 4,7 & 28,2 & 56,4 \\
\hline \multirow[t]{6}{*}{$(\mathrm{pH}=7.4)$} & E. cloacae & 2 & 20000 & $-0,15 \mathrm{t}$ & 6,7 & 40,2 & 80,4 \\
\hline & E. coli & 2 & 20000 & $-0,14 \mathrm{t}$ & 7,1 & 42,6 & 85,2 \\
\hline & S. aureus & 2 & 20000 & $-0,17 \mathrm{t}$ & 5,9 & 35,4 & 70,8 \\
\hline & S. marcescens & 2 & 20000 & $-0,20 \mathrm{t}$ & 5 & 30 & 60 \\
\hline & B. stearothermophilus & 2 & 20000 & $-0,04 \mathrm{t}$ & 25 & 150 & 300 \\
\hline & B. subtilis & 2 & 20000 & $-0,04 \mathrm{t}$ & 25 & 150 & 300 \\
\hline \multirow{5}{*}{$\begin{array}{l}\text { FORMALDEHYDE } \\
(\mathrm{pH}=6.5)\end{array}$} & A. calcoaceticus & 0,5 & 5000 & $-0,19 t$ & 5,2 & 31,2 & 62,4 \\
\hline & E. cloacae & 0,5 & 5000 & $-0,22 \mathrm{t}$ & 4,5 & 27 & 54 \\
\hline & S. marcescens & 0,5 & 5000 & $-0,48 \mathrm{t}$ & 2,1 & 12,6 & 25,2 \\
\hline & B. stearothermophilus & 0,5 & 5000 & $-0,10 \mathrm{t}$ & 10,9 & 65,4 & 130,8 \\
\hline & B. subtilis & 0,5 & 5000 & $-0,13 \mathrm{t}$ & 11,8 & 70,8 & 141,6 \\
\hline \multirow{7}{*}{$\begin{array}{l}\text { CHLORHEXIDINE } \\
(\mathrm{pH}=6.2)\end{array}$} & A. calcoaceticus & 0,4 & 4000 & $-0,24 t$ & 4,1 & 24,6 & 49,2 \\
\hline & E. cloacae & 0,4 & 4000 & $-0,12 \mathrm{t}$ & 8,3 & 49,8 & 99,6 \\
\hline & E. coli & 0,4 & 4000 & $-0,34 \mathrm{t}$ & 3 & 18 & 36 \\
\hline & S. aureus & 0,4 & 4000 & $-0,17 \mathrm{t}$ & 5,9 & 35,4 & 70,8 \\
\hline & S. marcescens & 0,4 & 4000 & $-0,25 \mathrm{t}$ & 4 & 24 & 48 \\
\hline & B. stearothermophilus & 2 & 20000 & $-0,11 \mathrm{t}$ & 9,1 & 54,6 & 109,2 \\
\hline & B. subtilis & 2 & 20000 & $-0,15 \mathrm{t}$ & 6,7 & 40,2 & 80,4 \\
\hline \multirow{7}{*}{$\begin{array}{l}\text { MINNCARE5 } \\
(\mathrm{pH}=2.3)\end{array}$} & A. calcoaceticus & 1 & 10000 & $-0,30 t$ & 3,4 & 20,4 & 40,8 \\
\hline & E. cloacae & 1 & 10000 & $-0,29 t$ & 3,5 & 21 & 42 \\
\hline & E. coli & 1 & 10000 & $-0,15 \mathrm{t}$ & 6,7 & 40,2 & 80,4 \\
\hline & S. aureus & 1 & 10000 & $-0,25 \mathrm{t}$ & 4 & 24 & 48 \\
\hline & S. marcescens & 1 & 10000 & $-0,28 \mathrm{t}$ & 3,6 & 21,6 & 43,2 \\
\hline & B. stearothermophilus & 1 & 10000 & $-0,11 t$ & 9,1 & 54,6 & 109,2 \\
\hline & B. subtilis & 1 & 10000 & $-0,17 \mathrm{t}$ & 5,9 & 35,4 & 70,8 \\
\hline \multirow{5}{*}{$\begin{array}{l}\text { HYDROGEN } \\
\text { PEROXIDE } \\
(\mathrm{pH}=3.3)\end{array}$} & E. cloacae & 1,5 & 15000 & $-0,56 \mathrm{t}$ & 1,8 & 10,8 & 21,6 \\
\hline & E. coli & 1,5 & 15000 & $-0,31 \mathrm{t}$ & 3,2 & 19,2 & 38,4 \\
\hline & S. aureus & 1,5 & 15000 & $-0,30 t$ & 3,4 & 20,4 & 40,8 \\
\hline & B. stearothermophilus & 26,5 & 265000 & $-0,21 t$ & 4,7 & 28,2 & 56,4 \\
\hline & B. subtilis & 1,5 & 15000 & $-0,02 \mathrm{t}$ & 55,2 & 331,2 & 662,4 \\
\hline
\end{tabular}

${ }^{1}$ Survival Curve: $\log \mathrm{Nf}=\log \mathrm{No}-1 / \mathrm{D} \times \mathrm{t} ; \mathrm{No}=$ bioburden; $\mathrm{Nf}=$ surviving population; ${ }^{2} \mathrm{t}=\mathrm{n} \times \mathrm{D}$, where: $\mathrm{t}=$ total exposure time $(\min ) ; \mathrm{n}=\log 10$ cycles reduced; $3 \mathrm{t}=\mathrm{n} * \mathrm{D}$ and $\mathrm{n}=6-\log 10, \mathrm{t}=$ exposure time for $6-\log 10$ reduction in bioburden(No); ${ }^{4} \mathrm{t}=\mathrm{n} * \mathrm{D}$ and $\mathrm{n}=12-\log 10, \mathrm{t}=$ exposure time for $12-\log 10$ reduction in bioburden (No); ${ }^{5} \mathrm{MINNCARE}=0.45 \%$ peracetic acid $+2.2 \%$ hydrogen peroxide 
The recommended concentration of formaldehyde is, in general, ten times more concentrated than the solution which was tested in this study; however, a $0.5 \%$ solution of formaldehyde reduced the strains of spore forming microorganisms by 12 logarithmic cycles $\left(12 \log _{10}\right)$, in less time than that recommended by the Brazilian Legislation (Brasil, 1988, 1999). B. subtilis and B. stearothermophilus, well known as biologic indicators (BIs) had a $6 \log _{10}$ reduction in 65 minutes and showed a $12 \log _{10}$ reduction from initial population levels in 142 minutes.

In a $2 \%$ gluteraldehyde solution, $B$. subtilis and $B$. stearothermophilus showed the same decimal reduction time ( $\mathrm{D}=25 \mathrm{~min})$, which is 3-4 times that of the $\mathrm{D}$ values found for the most resistant vegetative strains (E. coli and E. cloacae). The least resistant vegetative strains were $S$. marcescens, A. calcoaceticus and S. aureus.

Gluteraldehyde is a chemical agent used for high level disinfection, as it is capable of reducing the populations of sporulated microorganisms and is unaltered in the presence of organic material and does not react with synthetic materials or detergents. It is non-corrosive, and does not coagulate proteins which may be present on the surface of the item being disinfected. However, it is toxic and causes mucosal, skin and eye irritation and therefore users must be equipped with personal protection equipment (PPE). In Brazil, the recommended time for sterilization in gluteraldehyde solutions is between 8 and 10 hours (Brasil, 1978, 1988, 1999).

The biologic indicators (BIs) B. subtilis and B. stearothermophilus were reduced by $12 \log _{10}$ ( sterilization), after 5 hours of contact, and for semi-critical articles the disinfection time needed for a $6 \log _{10}$ reduction was three hours.

Combination of hydrogen peroxide $2.2 \%$ with peracetic acid $0.45 \%$ (Minncare) was effective against sporulated microorganisms, although E. coli, B. subtilis and $B$. stearothermophilus showed 2-3 times greater resistance than the most susceptible strains.

With a $1.5 \%$ solution of hydrogen peroxide, similar results were obtained to the use of a Minncare solution. Moreover, the use of peracetic acid caused a reduction of ten times the $\mathrm{D}$ value for $B$. subtilis. B. stearothermophilus showed a D value of 5 minutes in contact with $26.5 \%$ hydrogen peroxide (Brasil, 1988, 1999; Rutala, 1998).

Minncare $^{\circledR}$ is an odorless product that decomposes into innocuous byproducts, but is extremely corrosive and therefore the user must be suitably attired to use it.

Sodium hypochlorite $(\mathrm{NaOCl})$ and sodium dichloroisocyanurate $(\mathrm{NaDCC})$ were the chloride-based solutions tested. Chloride-based solutions react with organic material, and their antimicrobial activity drops off according to the concentration present. Thus, the chloride concentration must be sufficient to kill the microorganis$\mathrm{ms}$ expected. Pre-cleaning of the item, guaranteeing the removal of organic material and other contaminants, is essential so that the sanitizing agent can reach the microorganisms present.

For the inorganic solution of sodium hypochlorite $(\mathrm{Na} \mathrm{OCl})$ the $\mathrm{pH}$ determines its spectrum of action . Hydrogen chlorate is formed at a $\mathrm{pH}$ of 5-8 and is responsible for microbacterial action. (McDonnel, Russell, 1998). The dissociated form $\left(\mathrm{OCl}^{-}\right)$predominates in an alkaline $\mathrm{pH}$ and has very little antimicrobial activity. More concentrated solutions of sodium hypochlorite above $\mathrm{pH}$ of 8 do not liberate the active compounds to any substantial extent (Rutala, 1995).

The organic compound can be used in higher concentrations, as it permits the decomposition and liberation of slow acting chloride. Its greatest stability occurs at around $\mathrm{pH}$ 7. Given its stability, NADCC is easy to use and reproducibility of studies is simple.

Of the vegetative strains tested, A. calcoaceticus and E. coli were the most resistant to $0.1 \% \mathrm{NaDCC}$. S. marcescens, E. cloacae and S. aureus gave similar D values and were the most sensitive. B. subtilis. B. stearothermophilus needed 4 minutes to fall by 1 logarithmic cycle with $0.2 \%$ NaDCC.

The $\mathrm{D}$ values for vegetative microorganisms treated with a $0.025 \%$ solution of sodium hypochlorite $(\mathrm{pH} \sim 7)$ varied between 4.7 to 7.5 minutes for E. cloacae and $E$. coli; these values were similar to those found for exposure to a $0.1 \% \mathrm{NaDCC}$ solution.

\section{CONCLUSION}

This study shows that the suspensions under consideration are indications of the effectiveness of the disinfection procedures recommended by the Brazilian Legislation (BRASIL, 1988, 1999), but results may vary from product to product.

Chlorhexidine may be used to disinfect hands as it has low D values, but for an intermediate level of disinfection for instruments and equipment the use of $\mathrm{NaDCC}$ is recommended, due to its stability and low corrosive effects on materials and equipment. For critical items, hydrogen peroxide and peracetic acid can be used. Glutaraldehyde, although frequently used in sterilizing processes, has effectiveness comparable to formaldehyde solutions, where both can be used for shorter periods of time than those recommended.

The effectiveness of the formulations shows that these agents tested can be recommended for disinfection; but it is important that the cleaning, disinfection and sterili- 
zation programs established take into account the product, area or article to be treated.

\section{REFERENCES}

BACCAN, N.; ANDRADE, J. C.; GODINHO, O. E. S.; BARONE, J. S. Química analítica quantitativa elementar. São Paulo: Edgard Blücher, 1985. 308p.

BRASIL. Agência Nacional de Vigilância Sanitária (ANVISA). Resolução $n^{\circ} 12$ de 1978. Aprova NORMAS TÉCNICAS ESPECIAIS, do Estado de São Paulo, revistas pela CNNPA, relativas a alimentos (e bebidas), para efeito em todo território brasileiro. Available at: $<\mathrm{http}: / / \mathrm{www}$.anvisa.gov. br/legis/resol/12_78.htm>. Accessed on: 21 set. 2008.

BRASIL. Agência Nacional de Vigilância Sanitária (ANVISA). Portaria $n^{\circ} 15$, de 23 de agosto de 1988. Determina que o registro de produtos saneantes domissanitários com finalidade antimicrobiana seja procedido de acordo com as normas regulamentares. Available at: $<$ http://e-legis.anvisa. gov.br/leisref/public/showAct.php?id=18661\&word $>$. Accessed on: 15 set. 2008.

BRASIL. Agência Nacional de Vigilância Sanitária (ANVISA). Resolução $n^{\circ} 211$, de 18 de junho de 1999. Altera o texto do subitem 3 do item IV da Portaria 15 de 23 de agosto de 1988, que passa a ter a seguinte redação: “desinfetantes para indústrias em superfícies onde se dá o preparo, consumo e estocagem dos gêneros alimentícios, podendo utilizar, exclusivamente, os princípios ativos dos grupos C, D, E, F e H do SUBANEXO 1 e também a substância PERÓXIDO DE HIDROGÊNIO". Available at: <http://e-legis.anvisa. gov.br/leisref/public/showAct.php?id=18661\&word $>$. Accessed on: 15 set. 2008.

BRASIL. Agência Nacional de Vigilância Sanitária (ANVISA). Resolução n 1469 , de 13 de setembro de 2001. Indeferir o Pedido de Revalidação de Registro de Produto, de produtos farmacêuticos, conforme relação em anexo. Available at: $<\mathrm{http}$ ://www.anvisa.gov.br/legis/resol/1469_01re.htm>. Accessed on: 21 set. 2008.

CONRAD, R. N. Increasing in hand-alcohol consumption among medical staff in a general hospital as a result of introducing a training program and a visualization test. Infect. Control Hosp. Epidemiol., v.22, p.41-42, 2001.
CROSHAW, B. Disinfectant Testing - with particular reference to the Rideal-Walker and Kelsey-Sykes tests. In COLLINS, C. H.; ALLWOOD, M. C.; BLOOMFIELD, S. F.; FOX, A. Disinfectants: their use and evaluation of effectiveness. New York: Academic Press, 1981. p.1-14.

JACOBS, P. T.; WANG, J. H.; GORHAM, R. A.; ROBERTS, C. G. Disinfection, sterilization and antiseptics in health care. Champlain. New York: Polyscience Publishers, 1998. p.165-166.

MADIGAN, M. T.; MARTINKO, J. M.; PARKER, J. Brock biology of microorganisms. London: Pearson Education Publishers, 2002. p.696-707.

MAZZOLA, P. G.; PENNA, T. C. V.; MARTINS, A. M. Determination of decimal reduction time (D value) of chemical agents used in hospitals for disinfection purposes. BMC Infec. Dis., v.3, p.24-34, 2003.

INTERNATIONAL STANDARDS ORGANIZATION. ISO 11134: Sterilization of health care products - requirements for validation and routine control - industrial moist heat sterilization. 1994. Irreg. pag.

INTERNATIONAL STANDARDS ORGANIZATION. ISO 14937: Sterilization of health care products - general requirements for characterization of a sterilizing agent and the development, validation and routine control of a sterilization process for medical devices. 2000. Irreg. pag.

McDOnNELl, G.; RUSSELl, A. D. Antiseptics and desinfectants: activity, action, and resistance. Clin. Microbiol. Rev., v.12, p.147-179, 1999.

O ESTADO DE SÃO PAULO. Agência de Notícias. Available at: $<$ http//estado.com.br/jornal $>$. Accessed on: jan. 2001.

PENNA, T. C. V.; MAZZOLA, P. G.; MARTINS, A. M. The efficacy of chemical agents in cleaning and disinfection programs. BMC Infec. Dis., v.1, p.16, 2001.

PENNA, T. C. V.; MACHOSHVILI, I. A.; TAQUEDA, M. E. S. Bacillus stearothermophilus sporulation response to different composition media. PDA J. Pharm. Sci. Techn., v.52, p.198-208, 1998.

RUTALA, W. A. APIC guidelines for selection and use of disinfectants. Am. J. Infect. Control, v.23, p.313-342, 1995. 
RUTALA, W. A. Disinfection, sterilization and antiseptics in health care. New York: Polyscience Publishers, 1998. 292 p.

SPAULDING, E. H. Chemical disinfection of medical and surgical materials. In: BLOCK, S.S. Disinfection sterilization and preservation. Philadelphia: Lea \& Febiger, 1968. p.517-531.
UNITED STATES PHARMACOPEIAL CONVENTION. INC 12601. Validation and Qualification of Water purification, storage, and distribution systems. USP 24 NF 19 p.21552163.

Received for publication on $06^{\text {th }}$ August 2008. Accepted for publication on $13^{\text {th }}$ March 2009. 